\title{
Scientific openness faces reality check
}

Biologists must shake themselves out of their denial and voluntarily relinquish some of their freedom before it is too late, warned leading scientists and policymakers at a January 2003 meeting on science and security, held at the US National Academy of Sciences in Washington D.C. If scientists don't rise to the occasion, they run the risk of facing blanket restrictions created by undiscerning legislators.

Unlike physicists,

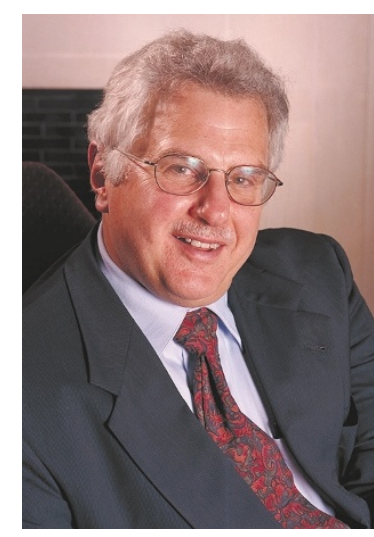

Bruce Alberts advocates openess in science biologists have thus

the meeting agreed that the primary responsibility for devising standards lies with scientists. Several experts invoked the Asilomar moratorium on DNA recombination as an example of the kind of scientist-led intervention the situation warrants.

Still, the opinions of most scientists at the meeting fell squarely on the side of scientific openness.

"We cannot build walls and attempt to segregate potentially sensitive information," said Bruce Alberts, president of the National Academy of Sciences.

"There is already classified research underway, just as there has always been," Alberts noted, adding that such research is currently protected. Research is now classified according to National Security Decision Directive 189 , created during the Reagan era and endorsed by the current administration, which says that, "to the maximum extent possible, the products of fundamental research [should] remain unrestricted."

But given the circumstances, Alberts said, "we could certainly develop a more sophisticated system than we have now."

Federal agencies can earmark certain research as classified before, but not after, funding a project, noted John Marburger, director of the White House Office on Science and Technology.

"This is a new concept for the life sciences but an old one for physics," Marburger said. But in contrast to nuclear research, regulating biological research is complicated because it is broad, easily hidden and more easily mastered, he said. Most biological research is also dual-use, meaning it has applications for both offensive and peaceful purposes.

Although American scientists are taking the lead in the discussions, whatever checks and balances they adopt will be meaningless unless they are honored internationally, added Alberts. "Anyone who thinks we can prevent others from learning and applying techniques is making a serious mistake," he said. "For example, right now India is advertising for biotechnology students, saying it can provide the same quality of education as that found in the US for about a tenth of the price."

The debate will probably continue in March at a meeting in Baltimore, Maryland, sponsored by the American Society of Microbiology. The goal is to create an organized system to "develop rational choices" for research, Alberts said. But "such a system requires more, not less, dissemination of scientific information."

Apoorva Mandavilli, New York \& Elizabeth Tracey, Washington, D.C.

\section{New Stanford institute sparks cloning quarrel}

The creation of Stanford University's privately funded institute to incorporate basic stem cell research into clinical medicine has set off a public squabble between President Bush's Council on Bioethics, the press and the institute's newly appointed director, Irving Weissman. The row underscores the misunderstandings about differences between therapeutic and reproductive cloning.

The imbroglio began 11 December, when Stanford announced that an anonymous donor had provided $\$ 12$ million to build the Stanford Cancer/Stem Cell Biology and Medicine Institute. In discussing the plans for the new facility, Weissman acknowledged that researchers would eventually create human embryos through nuclear transfer techniques, a procedure also known as therapeutic cloning. However, the Associated Press reported that Stanford would be "cloning human embryos," forcing Stanford to issue a statement explaining that "creating human stem cell lines is not equivalent to human cloning," and that the institute's plans were to create only cells, not human embryos.

On its website, Stanford claimed that the President's Council on Bioethics supported this view as well as its pro-

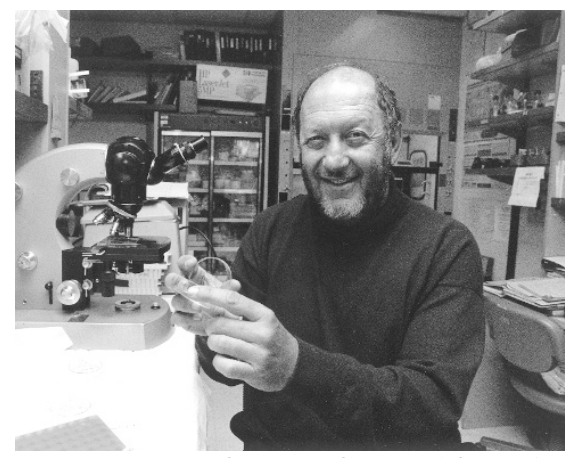

Irving Weissman objects to the term 'cloning'

posed research. But the council officially considers the work to be "cloning for biomedical research," and Leon 